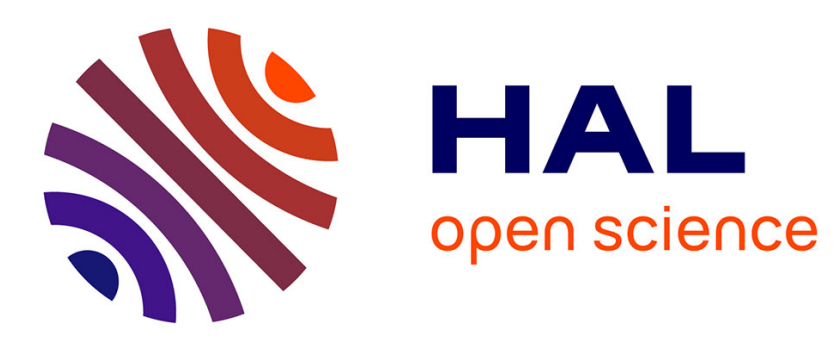

\title{
Indebtedness and macroeconomic imbalances in a monetary-union DSGE model
}

Florina-Cristina Badarau, Florence Huart, Ibrahima Sangaré

\section{To cite this version:}

Florina-Cristina Badarau, Florence Huart, Ibrahima Sangaré. Indebtedness and macroeconomic imbalances in a monetary-union DSGE model. 2013. hal-00996622

\section{HAL Id: hal-00996622 \\ https://hal.univ-lille.fr/hal-00996622}

Preprint submitted on 26 May 2014

HAL is a multi-disciplinary open access archive for the deposit and dissemination of scientific research documents, whether they are published or not. The documents may come from teaching and research institutions in France or abroad, or from public or private research centers.
L'archive ouverte pluridisciplinaire HAL, est destinée au dépôt et à la diffusion de documents scientifiques de niveau recherche, publiés ou non, émanant des établissements d'enseignement et de recherche français ou étrangers, des laboratoires publics ou privés. 


\section{Document de travail}

- [2013-33]

"Indebtedness and macroeconomic imbalances in a monetary-union DSGE"

Cristina Badarau, Florence Huart and Ibrahima Sangaré

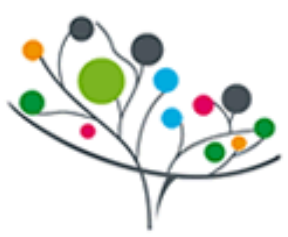

Université Lille Nord de France

Pole de Recherche

et dEnselgnement Superieur 


\section{"Indebtedness and macroeconomic imbalances in a monetary-union DSGE model"}

\section{Cristina Badarau, Florence Huart and Ibrahima Sangaré}

Laboratoire LAREFI. Université Bordeaux IV, Avenue Léon Duguit, 33608 Pessac cedex.

florinacristina.badarau@u-bordeaux4.fr

\section{Florence Huart}

PRES Université Lille Nord de France, Université Lille 1, Laboratoire EQUIPPE, EA 4018, Villeneuve d'Ascq, France

florence.huart@univ-lille1.fr

\section{Ibrahima Sangaré}

Laboratoire LAREFI. Université Bordeaux IV, Avenue Léon Duguit, 33608 Pessac Cedex

ibrahima.sangare@u-bordeaux4.fr 


\title{
Indebtedness and macroeconomic imbalances in a monetary-union DSGE model
}

\author{
Cristina Badarau* \\ Florence Huart $\dagger$ \\ Ibrahima Sangaréł
}

June 2013

\begin{abstract}
We build a two-country open-economy monetary union DSGE model in order to explain some macroeconomic imbalances in the euro area. We focus on the role of cyclical behaviour of public spending and sovereign risk premium. Pro-cyclical primary public expenditures in one country do not lead to higher interest rates on domestic public bonds in the short term as long as output growth helps financing public debt. Spillover effects on the other country can be positive on output as long as a real effective depreciation of the common currency leads to higher exports to the rest of the world.
\end{abstract}

Keywords: macroeconomic divergences, euro area, DSGE, risk premium, pro-cyclical fiscal policy, spillover effects

\section{JEL Classification: E63, F41}

We gratefully acknowledge the support of our research centers. Florence Huart is grateful for being invited at the LAREFI seminar in University Bordeaux IV (February 2013) and Ibrahima Sangaré thanks Hubert Jayet, the director of EQUIPPE, for being welcomed in the research center in University Lille 1 (April 2013).

* Laboratoire LAREFI. Université Bordeaux IV, Avenue Léon Duguit, 33608 Pessac Cedex. E-mail: florinacristina.badarau@u-bordeaux4.fr

† Laboratoire EQUIPPE. Université Lille 1, Faculté des Sciences Economiques et Sociales, Villeneuve d’Ascq 59655 Cedex France. E-mail: florence.huart@univ-lille1.fr

‡ Laboratoire LAREFI. Université Bordeaux IV, Avenue Léon Duguit, 33608 Pessac Cedex. E-mail: ibrahima.sangare@u-bordeaux4.fr 


\section{Introduction}

The euro area (EA) sovereign debt crisis in 2010-2012 highlights the issue of macroeconomic imbalances across member countries in particular with regard to divergent inflation rates, GDP growth rates, ratios of public deficits and debts to GDP, and current account balances. These imbalances emerged before the international financial crisis of 2008-2009, but the latter has exacerbated them. As a matter of fact, in a monetary union with common short-term nominal interest rates but disparate national inflation rates (due to cyclical or structural country-specific causes), short-term real interest rates are different across countries. In countries where the inflation rate was above the euro area average before the financial crisis, real interest rates were very low (Spain, Portugal, Greece) and even negative for short maturities (Ireland). On the contrary, in some countries with lower inflation rates, such as Germany, real interest rates were higher. Then, indebtedness of the private sector rose and boosted aggregate demand in the former group of countries (henceforth the G4) while domestic consumption and investment rose more slowly in Germany.

Over time, the G4 countries were bound to lose price competitiveness while Germany was likely to gain price competitiveness. Indeed, there have been rising current account deficits in those countries and current account surpluses in Germany (as well as in the Netherlands, Finland, Austria and Belgium). As a consequence, real depreciation was needed in countries with high current account deficits and a real appreciation was needed in countries with current account surpluses. As regards intra-EA real exchange rates, prices and wages had to grow slower in high-deficit countries and higher in countries with external surpluses. However, since 2008, the extent of adjustment has mostly relied on the high-deficit countries. As a consequence, the deflationary policies have been criticized for being harmful for Southern populations (in Greece, Spain or Portugal). As regards extra-EA real exchange rates, there has been an effective nominal depreciation of the euro over the years 20102012. However, the extent of the depreciation might not be sufficient for some countries.

Macroeconomic divergences across EA countries also stem from fiscal imbalances. Before the crisis, the public sector could borrow heavily as did the private sector in countries where interest rates have been lower since the entry into the euro area (given very low yield spreads on public bonds issued by EA governments relative to German bonds). Public saving decreased (in Greece and Portugal) and public deficits and debts have not been lowered as much as what was set in the fiscal rules of the Stability and Growth Pact. Moreover, public spending has been pro-cyclical in the EA, except in Finland (Fatás and Mihov, 2010). In some countries (Italy, France), the ratio of public debt to GDP has not risen much despite some persistent public deficits, because they benefited from a context of low interest rates (and interest payments). In most other EA countries, the ratio of public debt to GDP was decreasing over the 1999-2007 period. Hence, the current issue of public indebtedness has been caused by the financial crisis. The bail-out of the banking sector led to a sharp increase in the GDPpublic debt ratio (especially in Ireland) and the recession led to an increase in public expenditure and a decrease in tax revenues more or less in EA countries depending on the size of automatic stabilizers and the extent of discretionary measures. Then, interest expenditure grew faster in countries where the sovereign risk premium had increased much (the G4 countries, and Italy).

A higher sovereign default risk premium could arise because of a high level of public debt, fast rising public indebtedness, bad future prospects of economic growth or a higher probability of rescuing 
financially weak banks (see Mody and Sandri, 2011). Contagion effects could affect the long-term interest rates in other EA countries. From 2009, long-term interest rates of EA countries had comoved, but in late 2011, as the economic hardship of the Southern EA countries was aggravating, the public sectors of some countries suffered from rising borrowing costs (Austria, France, and Belgium) while in some other countries, they benefitted from decreasing borrowing costs (in particular, Finland, Germany, and the Netherlands). The sign of these spillover effects on EA countries mostly depended on their specific economic performance and financial position. The latter was at risk where domestic banks had much lent to the public and banking sectors of the G4 countries.

The EA crisis shows how financial difficulties of both public sector and banking sector are closely intertwined not only at the national level but also at the area-wide level. On the one hand, the banking sector rescue packages by governments could lead to higher sovereign bond risk premia (given the impact on implicit government liabilities) and consequently to greater difficulty repaying the debt. On the other hand, since banks hold sovereign bonds issued by EA governments, higher sovereign risk premia make their financial position weaker. As a result, banks decrease their lending activity or they increase interest rates on loans to the non-financial private sector (as in Greece and Portugal). Such behaviour impairs the transmission of the key interest rates of the European Central Bank (ECB) to interest rates on loans to households and firms. It aggravates divergences in the evolution of aggregate spending across EA countries. This negative spillover effect of higher sovereign risk premia on the borrowing costs of the non-financial private sector has lately been studied as a "sovereign risk channel" in a dynamic stochastic general equilibrium (DSGE) model of a closed economy (Corsetti et al, 2012) or in a two-country monetary union DSGE model (Roeger and in't Veld, 2013).

In this article, we want to explain macroeconomic imbalances among EA countries by taking into consideration various real and financial interdependencies between countries. In particular, we are interested in the role of sovereign risk premia and the cyclical behaviour of fiscal policy. We study their effects on the borrowing costs of other EA governments as well as of the private sector. Thus, we add the foreign public sector in the "sovereign risk channel" and show how the spillover effects can be positive, that is the public sector in other EA countries (such as Germany) may benefit from lower borrowing costs. To do so, we build a two-country monetary union DSGE model which combines the following elements: $i$ ) monetary union (MU) is open to the rest of the world (RoW); $i$ ) there is public indebtedness (with a constraint on debt accumulation) and external debt (the net foreign asset position of the nation); iii) there are deviations from the law of one price between both countries within MU and between each country and the RoW; iv) there is a financial accelerator mechanism; v) banks lend to domestic firms and to each government of both countries; and vi) there are three endogenous risk premia, namely a firm risk premium depending on the net worth-capital value ratio, a government risk premium depending on the public debt/GDP ratio, and a nation-wide risk premium depending on the net foreign asset (NFA) position.

In the literature on sovereign risk premium in DSGE models, the premium is determined in a closedeconomy (or closed-monetary union) framework. Since we consider an open-monetary union framework and consider a financial accelerator mechanism, we use a simple linear relationship between the sovereign risk premium and the gap between the level of public debt and a debt target. In Christoffel, Jaccard and Kilponen (2011), the risk premium is not linked to default but to a potential capital loss in case of selling the public bond before maturity. They show that pro-cyclical public 
expenditure leads to a higher bond premium. As pro-cyclical fiscal spending increases output and inflation variability, the central bank may react more aggressively to counteract higher inflation variability. This leads to higher interest rates and hence a higher bond risk premium. Their result is derived from a closed-economy DSGE model (estimated using U.S. data). In our model, pro-cyclical fiscal policy does not lead to a higher risk premium in the short term, because public debt increases less than in the case of a counter-cyclical fiscal policy. This is due to faster output growth and larger capital income tax receipts. Openness of both countries within the MU and with the RoW helps lowering the risk premium via the role of exports in output growth. In addition, the common central bank in the MU does not raise the common interest rate as much as in a closed-economy set-up, because the interest rate rule depends on average performance of member countries.

In other respects, in Bi (2012), there is a non-linear relationship between the sovereign risk premium and the level of debt: the risk premium rises if the government approaches the "fiscal limit", that is the maximum level of debt that the government is able or willing to service. In Corsetti et al (2012), a higher sovereign risk premium spills over to the borrowing cost of the private sector and amplifies macroeconomic fluctuations when the central bank cannot cut interest rates further (under a zero lower bound constraint). Furthermore, Roeger and in't Veld (2013) analyze the sovereign risk channel in a euro area DSGE model, where banks are exposed to the risk of a decline in bond prices. They compare the contractionary effects of fiscal consolidation with the effects of no-consolidation in a context of rising public debt. In the latter case, higher sovereign risk premia spillover into higher costs of borrowing for households. In their model, banks lend to households and invest in domestic government bonds and bonds issued by foreign banks, but they do not lend to the corporate sector, while in ours, banks lend to the domestic corporate sector, domestic government and foreign government in the rest of the union (RoU) but not to the households. The latter hold bonds issued by the RoW.

In our model, there are several channels by which macroeconomic performance of MU countries is interdependent and may diverge. The trade channel works through both intra-MU and extra-MU change in net exports and bilateral real exchange rates. The credit channel concerns the transmission of the common monetary policy to domestic production and inflation in both MU countries via the banking sector's balance sheet. The share of consumers' deposits that banks lend to borrowers depends on economic activity. As for the fiscal channel, it denotes the fiscal causes of macroeconomic divergences across MU countries. We also compare the implications of a countercyclical vs. pro-cyclical reaction of public primary expenditure to deviations of output from its steady-state level. Finally, there is also a sovereign risk channel: given banks' holdings of public bonds issued by governments of both MU countries, higher public indebtedness has an impact on the bank lending to firms.

We find that pro-cyclical spending in one country makes it harder to stabilize debt and accentuates negative spillover effects on aggregate spending (absorption) in the other country. A higher risk premium in one country has two opposite effects on the other country: borrowing costs are lower for the public sector but higher for the non-financial private sector. In all cases, the other country can benefit from positive spillover effects on output as long as the effective real depreciation of the common currency leads to higher net exports to the RoW. 
In what follows, we set the DSGE model of a two-country open-economy monetary union (section 2). We then describe the calibration and explain the results of our simulations (section 3). We finally conclude (section 4).

\section{A two-country open-economy monetary union DSGE model with risk premia}

We consider two symmetric countries of equal size, home $(h)$ and foreign $(f)$. They are members of a monetary union and are open to the rest of the world $(w)$ which is fully exogenous (in the small open economy perspective). The model contains price stickiness, monopolistic competition in final goods market, capital adjustment costs, incomplete pass-through of exchange rate via law of one price deviation, financial market frictions and fiscal policy instruments.

Each economy is populated by households, banks, government and three types of producers: entrepreneurs, capital producers, and retailers (domestic and imported goods retailers). There is a common monetary authority that sets the unique nominal risk-free interest rate for both countries. Capital producers build new capital and sell it to the entrepreneurs. Entrepreneurs produce wholesale goods and sell them to domestic goods retailers. Domestic and imported goods retailers set nominal prices of final goods à la Calvo (1983). Banks convert households' deposits in loans to finance the government deficit and the entrepreneurial purchase of capital. Each government decides upon fiscal policy.

Our model shares some common features with those of other DSGE models of the euro area. Indeed, there are both real rigidities (habit formation in consumption and adjustment costs in investment) and nominal rigidities (Calvo probability of not being able to reset prices) as in Smets and Wouters (2002), Coenen, McAdam and Straub (2008), Erceg and Lindé (2012). Each government finances public purchases (consumption and transfers) by levying taxes (on consumption and capital income) and issuing debt. We ignore seignoriage and taxes on labour services and wages unlike Coenen, McAdam and Straub (2008). Following Christoffel, Jaccard and Kilponen (2011), we assume that each government adjusts the fiscal instrument (public consumption in our model) with reaction to output growth and the level of debt (in deviation with its steady-state level). We add some degree of inertia in the adjustment of fiscal instrument.

This model has also specific features that distinguish it from standard models of monetary union (MU). The exposure of domestic banks to foreign government debt in the rest of the union (RoU) allows us to study the potential contagion effects working through sovereign debts within the monetary union. Moreover, since monetary union is open with the rest of the world (RoW), we can take into account both intra and extra-zone net exports of each country and underline the importance of trade openness in times of regional economic turmoil. Finally, deviations from the law of one price and imperfect exchange-rate pass-through capture the fact that there are country-specific factors of inflation. At least, they cushion the impact of price variations in one country on the other country. 


\subsection{Households}

Each country $i \in\{h, f\}$ is populated by a continuum of unit mass households with infinite life. The representative household of country $i$ maximizes the following expected discounted sum of utilities:

$$
E_{t} \sum_{t=0}^{\infty} \beta^{t}\left(\frac{\left(C_{t}^{i}-h C_{t-1}^{i}\right)^{1-\sigma}}{1-\sigma}-\frac{\left(N_{t}^{i}\right)^{1+\eta}}{1+\eta}\right)
$$

where $C_{t}^{i}$ is aggregate consumption and $N_{t}^{i}$ denotes the number of hours worked. $E_{t}$ is the conditional expectation operator. The parameters $0<\beta<1, \sigma>0, \eta>0$ and $0<h<1$ are, respectively, the subjective discount factor, the inverse intertemporal elasticity of substitution, the inverse of the Frisch elasticity of labour supply and the parameter that controls habit persistence.

The household's period-by-period budget constraint is defined by:

$$
\begin{aligned}
\left(1+\tau_{c, t}^{i}\right) C_{t}^{i}+ & \frac{D_{t}^{i}}{P_{t}^{i}}+\frac{S_{t} B_{w, t}^{i}}{P_{t}^{i}} \\
& =\frac{W_{t}^{i}}{P_{t}^{i}} N_{t}^{i}+R_{t-1} \frac{D_{t-1}^{i}}{P_{t}^{i}}+R_{w, t-1} \Psi_{b, t-1}^{i}\left(b_{t-1}^{i}, Z_{t-1}^{i}\right) \frac{S_{t} B_{w, t-1}^{i}}{P_{t}^{i}}+\frac{T R_{t}^{i}}{P_{t}^{i}}+\Lambda_{t}^{i}
\end{aligned}
$$

where $P_{t}^{i}$ is the consumer price index (CPI), $W_{t}^{i}$ the nominal wage, $D_{t}^{i}$ nominal deposits that pay gross nominal interest rate $R_{t}$ and $B_{w, t}^{i}$ nominal internationally traded bonds, denominated in rest of the world currency, that pay a gross nominal interest rate $R_{w, t-1} \Psi_{b, t-1}^{i} . S_{t}$ is the nominal exchange rate (expressed in terms of units of home currency per unit of foreign currency). $\tau_{c, t}^{i}, T R_{t}^{i}$ and $\Lambda_{t}^{i}$ are, respectively, distortionary tax rate on consumption, government transfers and real profits from the monopolistic sector. Finally, $\Psi_{b, t}^{i}$ represents a risk premium that is a function of the economy's real aggregate level of net-foreign asset position in percentage of steady-state output, as follows:

$$
\Psi_{b, t}^{i}\left(b_{t}^{i}, Z_{t}^{i}\right)=\exp \left(-\psi_{b}^{i}\left(\frac{S_{t} B_{w, t}^{i}}{Y P_{t}^{i}}\right)+Z_{t}^{i}\right)
$$

where $b_{t}^{i} \equiv \frac{S_{t} B_{w, t}^{i}}{Y P_{t}^{i}}$ is real aggregate net-foreign asset position in percentage of steady-state GDP; $\psi_{b}^{i}>0$ is a measure of the elasticity of the risk premium with respect to net-foreign asset (NFA) position. Whenever the NFA is negative, the nation is a net borrower. The variable $Z_{t}^{i}$ is an exogenous shock on risk premium defined by $\log \left(Z_{t}^{i}\right)=\rho_{z} \log \left(Z_{t-1}^{i}\right)+e_{z, t}$ with $e_{z, t} \sim i . i . d\left(0, \sigma_{e_{z}}^{2}\right)$. The term $\Psi_{b, t}^{i}\left(b_{t}^{i}, Z_{t}^{i}\right)$ is assumed to be strictly decreasing in $b_{t}^{i}$ and satisfies $\Psi_{b}^{i}(0,0)=1$. It captures imperfect integration in the international financial markets and ensures a well-defined steady-state in the model (Schmitt-Grohé and Uribe, 2003).

Households choose the paths for $\left\{C_{t}^{i}, N_{t}^{i}, D_{t}^{i}, B_{w, t}^{i}\right\}_{0}^{\infty}$ in order to maximize (1) subject to the budget constraint in (2). The following optimality conditions hold:

$$
\begin{aligned}
& \left(C_{t}^{i}-h C_{t-1}^{i}\right)^{-\sigma}-\beta h E_{t}\left(C_{t+1}^{i}-h C_{t}^{i}\right)^{-\sigma}=\lambda_{t}^{i}\left(1+\tau_{c, t}^{i}\right) \\
& \lambda_{t}^{i} \frac{W_{t}^{i}}{P_{t}^{i}}=\left(N_{t}^{i}\right)^{\eta}
\end{aligned}
$$




$$
\begin{aligned}
& -\frac{\lambda_{t}^{i} S_{t}}{P_{t}^{i}}+E_{t} \beta \frac{\lambda_{t+1}^{i} S_{t+1}}{P_{t+1}^{i}} R_{w, t} \Psi_{b, t}^{i}\left(b_{t}^{i}, Z_{t}^{i}\right)=0 \\
& -\frac{\lambda_{t}^{i}}{P_{t}^{i}}+E_{t} \beta \frac{\lambda_{t+1}^{i}}{P_{t+1}^{i}} R_{t}=0
\end{aligned}
$$

$\lambda_{t}^{i}$ is the Lagrangian multiplier in (4), (5), (6) and (7).

The final good, $X_{t}^{i}$, is allocated to consumption, $C_{t}^{i}$, investment, $I_{t}^{i}$, and public spending, $G_{t}^{i}$. It is an aggregate function of goods produced in the home country, $X_{i, t}^{i}$, in the RoU, $X_{k, t}^{i}$, and in the RoW, $X_{w, t}^{i}$ :

$$
X_{t}^{i}=\left[\left(1-a_{1}^{i}-a_{2}^{i}\right)^{\frac{1}{\theta}}\left(X_{i, t}^{i}\right)^{\frac{\theta-1}{\theta}}+\left(a_{1}^{i}\right)^{\frac{1}{\theta}}\left(X_{k, t}^{i}\right)^{\frac{\theta-1}{\theta}}+\left(a_{2}^{i}\right)^{\frac{1}{\theta}}\left(X_{w, t}^{i}\right)^{\frac{\theta-1}{\theta}}\right]^{\frac{\theta}{\theta-1}}
$$

for $X=\{C, I, G\} ; i, k \in\{h, f\}$ and $i \neq k$.

The parameters $\theta>1, a_{1}^{i}$, and $a_{2}^{i}$ are, respectively, the elasticity of substitution between the three types of goods, the share of imported goods from the RoU and the share of imported goods from the RoW. We suppose that these shares are identical reciprocally between each country $i \in\{h, f\}$ of the union and the RoW. Therefore, the fraction $\left(1-a_{1}^{i}-a_{2}^{i}\right)$ is the degree of home bias in consumption, investment and public goods.

The price index (CPI) associated to (8) is given by:

$$
P_{t}^{i}=\left[\left(1-a_{1}^{i}-a_{2}^{i}\right)\left(P_{i, t}^{i}\right)^{1-\theta}+a_{1}^{i}\left(P_{k, t}^{i}\right)^{1-\theta}+a_{2}^{i}\left(P_{w, t}^{i}\right)^{1-\theta}\right]^{\frac{1}{1-\theta}}
$$

where $P_{i, t}^{i} P_{k, t}^{i}$ and $P_{w, t}^{i}$ are, respectively, the domestic price of home goods, the domestic price of imported goods from the RoU and the domestic price of imported goods from the RoW.

We define $\quad X_{i, t}^{i} \equiv\left(\int_{0}^{1} X_{i, t}^{i}(j)^{\frac{\chi-1}{\chi}} d_{j}\right)^{\frac{\chi}{\chi-1}}, \quad X_{k, t}^{i} \equiv\left(\int_{0}^{1} X_{k, t}^{i}(j)^{\frac{\chi-1}{\chi}} d_{j}\right)^{\frac{\chi}{\chi-1}} \quad$ and $X_{w, t}^{i} \equiv\left(\int_{0}^{1} X_{w, t}^{i}(j)^{\frac{\chi-1}{\chi}} d_{j}\right)^{\frac{\chi}{\chi-1}}$ as the composite aggregates of differentiated varieties produced domestically, inside and outside the monetary union, respectively, with $\chi$ being the elasticity of substitution between varieties originating in the same country; $X_{i, t}^{i}(j), X_{k, t}^{i}(j)$ and $X_{w, t}^{i}(j)$ being a typical variety $j$ of domestic goods, imported goods from the RoU and imported goods from RoW, respectively. The corresponding prices are deduced easily and are given by, respectively:

$P_{i, t}^{i}=\left(\int_{0}^{1} P_{i, t}^{i}(j)^{1-\chi} d_{j}\right)^{\frac{1}{1-\chi}}, \quad P_{k, t}^{i}=\left(\int_{0}^{1} P_{k, t}^{i}(j)^{1-\chi} d_{j}\right)^{\frac{1}{1-\chi}}, \quad P_{w, t}^{i}=\left(\int_{0}^{1} P_{w, t}^{i}(j)^{1-\chi} d_{j}\right)^{\frac{1}{1-\chi}}$, where $P_{i, t}^{i}(j)$ (respectively $P_{k, t}^{i}(j)$ and $P_{w, t}^{i}(j)$ ) is the price of a typical variety $j$ produced in the home country (respectively imported prices from the RoU and the RoW). 
The optimal demands for domestic, RoU and RoW goods, are derived from expenditure minimization $^{4}$ :

$$
\begin{aligned}
X_{i, t}^{i} & =\left(1-a_{1}^{i}-a_{2}^{i}\right)\left(\frac{P_{i, t}^{i}}{P_{t}^{i}}\right)^{-\theta} X_{t}^{i} \\
X_{k, t}^{i} & =a_{1}^{i}\left(\frac{P_{k, t}^{i}}{P_{t}^{i}}\right)^{-\theta} X_{t}^{i} \\
X_{w, t}^{i} & =a_{2}^{i}\left(\frac{P_{w, t}^{i}}{P_{t}^{i}}\right)^{-\theta} X_{t}^{i}
\end{aligned}
$$

\subsection{Open-economy relations}

This section outlines the key relations that describe the terms of trade, the real exchange rates and the law of one price deviations. For each country $i, k \in\{h, f\}$ and $i \neq k$, we define the bilateral terms of trade as:

$$
\operatorname{TOT}_{k, t}^{i}=\frac{P_{k, t}^{i}}{P_{i, t}^{i}} \text { and } \operatorname{TOT}_{w, t}^{i}=\frac{P_{w, t}^{i}}{P_{i, t}^{i}}
$$

From (9), the terms of trade can be related to the CPI-PPI ratio as follows:

$$
\frac{P_{t}^{i}}{P_{i, t}^{i}}=\left[\left(1-a_{1}^{i}-a_{2}^{i}\right)+a_{1}^{i}\left(\text { TOT }_{k, t}^{i}\right)^{1-\theta}+a_{2}^{i}\left(\text { TOT }_{w, t}^{i}\right)^{1-\theta}\right]^{\frac{1}{1-\theta}}
$$

We assume that the law of one price (LOP) holds for the export sector, but there is incomplete passthrough in the import sector. This assumption is motivated by the existence of monopolistic domestic importers in the union that practice local currency pricing (Devereux and Engel, 2001). This behaviour can make the price of the foreign goods in the domestic market temporarily deviate from the producer price level in the country of origin. The wedge between these two prices is called the law of one price gap (LOPG) and is given by, bilaterally:

$$
L O P G_{k, t}^{i}=\frac{P_{k, t}^{k}}{P_{k, t}^{i}} \text { and } L O P G_{w, t}^{i}=\frac{S_{t} P_{w, t}^{w}}{P_{w, t}^{i}}
$$

where $P_{k, t}^{k}$ and $P_{w, t}^{w}$ are domestic prices in country $k$ of the union and in the RoW.

Similarly, we define the bilateral real exchange rates as follows:

$$
R E R_{k, t}^{i}=\frac{P_{t}^{k}}{P_{t}^{i}} \text { and } R E R_{w, t}^{i}=\frac{S_{t} P_{t}^{w}}{P_{t}^{i}}
$$

\footnotetext{
${ }^{4}$ The optimization program is $\min _{C_{i, t}^{i},}, c_{k, t}^{i}, c_{w, t}^{i}, C_{t}^{i} P_{i, t}^{i} C_{i, t}^{i}+P_{k, t}^{i} C_{k, t}^{i}+P_{w, t}^{i} C_{w, t}^{i}=P_{t}^{i} C_{t}^{i}$ subject to the following constraint: $C_{t}^{i}=\left[\left(1-a_{1}-a_{2}\right)^{\frac{1}{\theta}}\left(C_{i, t}^{i}\right)^{\frac{\theta-1}{\theta}}+\left(a_{1}\right)^{\frac{1}{\theta}}\left(C_{k, t}^{i}\right)^{\frac{\theta-1}{\theta}}+\left(a_{2}\right)^{\frac{1}{\theta}}\left(C_{w, t}^{i}\right)^{\frac{\theta-1}{\theta}}\right]^{\frac{\theta}{\theta-1}}$.
} 
Finally, we can express the effective terms of trade, the effective law of one price gap and the effective real exchange rate, for each country $i \in\{h, f\}$ as:

$$
\begin{aligned}
& \operatorname{TOT}_{t}^{i}=\left(T_{O T}^{i}\right)_{k, t}^{a_{1}^{i}}\left(\operatorname{TOT}_{w, t}^{i}\right)^{a_{2}^{i}} \\
& L O P G_{t}^{i}=\left(L O P G_{k, t}^{i}\right)^{a_{1}^{i}}\left(L O P G_{w, t}^{i}\right)^{a_{2}^{i}} \\
& R E R_{t}^{i}=\left(R E R_{k, t}^{i}\right)^{a_{1}^{i}}\left(R E R_{w, t}^{i}\right)^{a_{2}^{i}}
\end{aligned}
$$

Assuming that the two countries $\{h, f\}$ are of the same size in the monetary union, the effective real exchange rate for the union is therefore:

$$
R E R_{t}^{u}=\left(R E R_{t}^{h}\right)^{\frac{1}{2}}\left(R E R_{t}^{f}\right)^{\frac{1}{2}}=\left(R E R_{w, t}^{h}\right)^{\frac{a_{2}^{i}}{2}}\left(R E R_{w, t}^{f}\right)^{\frac{a_{2}^{i}}{2}}
$$

which can be written also in terms of euro nominal exchange rate:

$$
R E R_{t}^{u}=\frac{S_{t} P_{t}^{w}}{P_{t}^{u}}
$$

where $P_{t}^{u}$ and $P_{t}^{w}$ are CPI of the monetary union and the rest of the world. ${ }^{5}$

\subsection{Production sector}

\subsubsection{Entrepreneurs}

The entrepreneurs play an important role here because their presence allows us to introduce the financial accelerator mechanism. As in Bernanke et al. (1999), entrepreneurs manage a continuum of firms $j \in[0,1]$ that produces, by using $K_{t}^{i}$ units of capital and $N_{t}^{i}$ units of labour, wholesale (intermediate) goods in a perfectly competitive market according to the following technology:

$$
Y_{t}^{i}(j)=A_{t}^{i} K_{t}^{i}(j)^{\alpha} N_{t}^{i}(j)^{1-\alpha}
$$

where $A_{t}^{i}$ is a technological shock that is common to all firms and follows a stationary first-order autoregressive process : $\log \left(A_{t}^{i}\right)=\rho_{A} \log \left(A_{t-1}^{i}\right)+e_{A, t}$, with $e_{A, t} \sim i . i . d\left(0, \sigma_{e_{A}}^{2}\right) ; \alpha \in[0,1]$ is the share of capital in the production technology.

The representative firm maximizes its profit by choosing $K_{t}^{i}$ and $N_{t}^{i}$ subject to the production function (22). The first-order conditions for this optimization problem are:

$$
\begin{gathered}
w_{t}^{i}=(1-\alpha) m c_{t}^{i} \frac{Y_{t}^{i}}{N_{t}^{i}} \frac{P_{i, t}^{i}}{P_{t}^{i}} \\
m p c_{t}^{i}=\alpha m c_{t}^{i} \frac{Y_{t}^{i}}{K_{t}^{i}} \frac{P_{i, t}^{i}}{P_{t}^{i}}
\end{gathered}
$$

\footnotetext{
${ }^{5}$ The way we write the real effective exchange rate means that an increase in this variable denotes an effective real depreciation of the common currency with regard to the foreign currency (RoW).
} 
where $m c_{t}^{i}$ is the Lagrangian multiplier associated with the production function (22) and denotes the real marginal cost; $w_{t}^{i}$ is the real wage; and $m p c_{t}^{i}$ is the real marginal productivity of capital.

Entrepreneurs are risk neutral and borrow to finance a share of capital used in the production process. As in Bernanke et al. (1999), to ensure that they never accumulate enough funds to fully self-finance their own activities entirely, we assume that they have a finite expected horizon. In each period $t$, entrepreneurs face a constant probability $(1-v)$ of leaving the economy. We follow Christensen and Dib (2008) in allowing newly entering entrepreneurs to inherit a fraction of the net worth of those firms which exit from the business. This assumption is made in order to ensure that new entrepreneurs start out with a positive net worth. ${ }^{6}$

At the end of each period, entrepreneurs purchase capital, $K_{t+1}^{i}$, that will be used in the next period at the real price $q_{t}^{i}$. Thus, the total funding needed by an entrepreneur to purchase capital is $q_{t}^{i} K_{t+1}^{i}$. The capital acquisition is financed partly by their net worth, $N W_{t+1}^{i}$, and by borrowing,

$q_{t}^{i} K_{t+1}^{i}-N W_{t+1}^{i}$, from a financial intermediary. Financial intermediaries (banks) obtain their funds from household deposits. Their activities are described below (see section 2.4.).

In optimum, the entrepreneur's aggregate demand for capital in the economy depends on the expected marginal return and the expected marginal financing cost at $t+1$. Thus, the capital demand must satisfy the following differentiation between the ex post marginal return on capital, $E_{t}\left(R_{K, t+1}^{i}\right)$, and the marginal productivity of capital at $t+1, m p c_{t}^{i}$, which is the rental rate of capital:

$$
E_{t}\left(R_{K, t+1}^{i}\right)=E_{t}\left[\frac{\left(1-\tau_{K, t}^{i}\right) m p c_{t+1}^{i}+(1-\delta) q_{t+1}^{i}}{q_{t}^{i}}\right]
$$

where $\delta$ is the capital depreciation rate, $\tau_{K, t}^{i}$ is the tax rate on capital-income (whose introduction here is a specific feature of our model) and $(1-\delta) q_{t+1}^{i}$ is the value of one unit of capital used in $t+1$.

Following Bernanke et al. (1999), we assume the existence of an agency problem that makes external finance more expensive than internal finance, because financial intermediaries are facing costs for auditing the performance of entrepreneurs. However, entrepreneurs observe the random outcome of their investments costlessly and decide whether to repay their debt or to default. If they default, the lenders audit the project and seize whatever they find. As demonstrated in Bernanke et al. (1999), the optimal financial contract between borrower and lender implies an external finance premium (the difference between the cost of external and internal finance), $\Psi_{\mathrm{E}, t}^{i}(\cdot)$, that reflects the existence of auditing costs and depends on the entrepreneur's leverage ratio (capital to net worth ratio).

Accordingly, the entrepreneur's demand for capital satisfies, optimally, the equality between expected return on capital and gross premium for external finance plus the gross real opportunity costs equivalent to the gross real interest rate on loans ${ }^{7}$ :

\footnotetext{
${ }^{6}$ In contrast, Bernanke et al. (1999) ensure this by assuming that entrepreneurs also work. This difference does not affect the results.

${ }^{7}$ For details, see Bernanke et al. (1999).
} 


$$
E_{t}\left(R_{K, t+1}^{i}\right)=E_{t}\left[\Psi_{\mathrm{E}, t+1}^{i}(\cdot) \frac{R_{L, t}^{i}}{\pi_{t+1}^{i}}\right]
$$

where $R_{L, t}^{i}$ is the gross nominal interest rate on banks loans; $\Psi_{\mathrm{E}, t+1}^{i}(\cdot)$ is the function that describes how the external finance premium depends on the financial position of the firm and is given by: $\Psi_{\mathrm{E}, t+1}^{i}(\cdot)=\left(\frac{N W_{t+1}^{i}}{q_{t}^{i} K_{t+1}^{i}}\right)^{-\gamma}$ with $\left(\Psi_{\mathrm{E}, t+1}^{i}(\cdot)\right)^{\prime}<0, \Psi_{\mathrm{E}}^{i}(1)=1$ and $\gamma$ is the elasticity of the external finance premium with respect to firm's leverage ratio. Thus, the external finance premium is an equilibrium inverse function of the aggregate financial position in the economy, expressed by the leverage ratio. Equation (26) provides the basis for the financial accelerator. If entrepreneur's net worth goes up, the external finance premium falls, the cost of borrowing falls and firms get cheaper access to credit.

Aggregate entrepreneurial net worth accumulation of the economy depends on profits earned in previous periods plus the bequest, $\Omega_{t}^{i}$, that newly entering entrepreneurs receive from entrepreneurs who leave the economy, and evolves according to:

$$
N W_{t+1}^{i}=v\left[R_{K, t}^{i} q_{t-1}^{i} K_{t}^{i}-\frac{R_{L, t-1}^{i}}{\pi_{t}^{i}}\left(\frac{N W_{t}^{i}}{q_{t-1}^{i} K_{t}^{i}}\right)^{-\gamma}\left(q_{t-1}^{i} K_{t}^{i}-N W_{t}^{i}\right)\right]+(1-v) \Omega_{t}^{i}
$$

\subsubsection{Capital producers}

Competitive capital producers use a linear technology to produce new capital $K_{t+1}^{i}$ from final investment goods $I_{t}^{i}$ and existing capital stock leasing from entrepreneurs without costs. When producing capital, they are subject to quadratic capital adjustment costs specified as

$$
\frac{\psi_{I}}{2}\left(\frac{I_{t}^{i}}{K_{t}^{i}}-\delta\right)^{2} K_{t}^{i}
$$

The aggregate capital stock used by producers in each economy $i$ evolves as follow:

$$
K_{t+1}^{i}=\left[\frac{I_{t}^{i}}{K_{t}^{i}}-\frac{\psi_{I}}{2}\left(\frac{I_{t}^{i}}{K_{t}^{i}}-\delta\right)^{2}\right] K_{t}^{i}+(1-\delta) K_{t}^{i}
$$

where $\psi_{I}>0$ is the parameter that measures the adjustment costs elasticity.

Capital producers face an optimization problem which consists, in real terms, in choosing the level of investment that maximizes their profits:

$$
\max _{I_{t}^{i}}\left\{q_{t}^{i} I_{t}^{i}-I_{t}^{i}-\frac{\psi_{I}}{2}\left(\frac{I_{t}^{i}}{K_{t}^{i}}-\delta\right)^{2} K_{t}^{i}\right\}
$$

The following equilibrium condition holds:

$$
q_{t}^{i}-\psi_{I}\left(\frac{I_{t}^{i}}{K_{t}^{i}}-\delta\right)=1
$$


which is the standard Tobin's Q equation that links the price of capital to the marginal adjustment costs.

When $\psi_{I}=0$ (no adjustment costs), the capital price, $q_{t}^{i}$ is constant and equal to 1 . This shows that capital adjustment costs imply necessarily the capital price $\left(q_{t}^{i}\right)$ variation and therefore contribute to the volatility of entrepreneurial net worth.

\subsubsection{Retailers: price and inflation dynamics}

The existence of retailers provides the source of nominal stickiness in the economy. Retailers take wholesale goods as inputs, repackage these costlessly, and sell them in a monopolistically competitive market. There are domestic goods retailers and imported goods retailers. Following Calvo (1983), we assume that retailers set nominal prices on a staggered basis: at each period, a fraction $\left(1-\phi^{i}\right)$ of retailers are randomly selected to set new prices while the remaining fraction $\phi^{i}$ of retailers keep their prices unchanged. For simplicity, these fractions are assumed to be equals within the two groups of retailers.

All home goods retailers purchase the wholesale goods from entrepreneurs at a price equal to the entrepreneurs' nominal marginal cost. Each retailer $j$ of them setting price at $t$ will choose the optimal price, $\widetilde{P}_{i, t}^{i}$, that maximizes the expected profits for $s$ periods, so that:

$$
\max _{\widetilde{P}_{i, t}^{i}(j)} E_{t}\left\{\sum_{s=0}^{\infty}\left(\beta \phi^{i}\right)^{s} \frac{\lambda_{t+s}^{i}}{\lambda_{t}^{i}}\left[Y_{i, t+s}^{i}(j)\left(\widetilde{P}_{i, t}^{i}(j)-P_{i, t+s}^{i} m c_{t+s}^{i}\right)\right]\right\}
$$

subject to the demand function,

$Y_{i, t+s}^{i}(j)=\left(\frac{\widetilde{P}_{i, t+s}^{i}(j)}{P_{i, t+s}^{i}}\right)^{-\chi} Y_{i, t+s}^{i}$, where $\frac{\lambda_{t+s}^{i}}{\lambda_{t}^{i}}$ is the households' marginal utilities ratio between $t+s$ and $t$.

The first-order condition for this problem yields,

$$
\widetilde{P}_{i, t}^{i}(j)=\frac{\chi}{\chi-1} \frac{E_{t}\left\{\sum_{s=0}^{\infty}\left(\beta \phi^{i}\right)^{s} \lambda_{t+s}^{i} Y_{i, t+s}^{i}(j) P_{i, t+s}^{i} m c_{t+s}^{i}\right\}}{E_{t}\left\{\sum_{s=0}^{\infty}\left(\beta \phi^{i}\right)^{s} \lambda_{t+s}^{i} Y_{i, t+s}^{i}(j)\right\}}
$$

Aggregating across all retailers, the price index for domestically produced goods is given by,

$$
P_{i, t}^{i}=\left[\left(1-\phi^{i}\right)\left(\widetilde{P}_{i, t}^{i}\right)^{1-\chi}+\phi^{i}\left(P_{i, t-1}^{i}\right)^{1-\chi}\right]^{\frac{1}{1-\chi}}
$$

Combining log-linearized versions of equations (32) and (33) yields an expression of the inflation rate for domestically produced goods, defined by the following New Keynesian Phillips curve:

$$
\hat{\pi}_{i, t}^{i}=\beta E_{t} \hat{\pi}_{i, t+1}^{i}+\frac{\left(1-\phi^{i}\right)\left(1-\beta \phi^{i}\right)}{\phi^{i}} \widehat{m c}_{t}^{i}
$$


where $m c_{t}^{i}$ is the real marginal cost, $\pi_{i, t}^{i}=\left(\frac{P_{i, t}^{i}}{P_{i, t-1}^{i}}\right)$ is domestic inflation and variables with hats are log deviations from their steady-state values.

Similarly, imported goods retailers purchase the products from foreign producers at the wholesale price, $P_{G, t}^{i}$. At the wholesale level, the law of one price holds. Thus, $P_{G, t}^{i}=P_{k, t}^{k}$ and $P_{G, t}^{i}=S_{t} P_{w, t}^{w}$ are the wholesale prices (nominal marginal costs) for goods coming from the RoU and the RoW, respectively. But at the retail level, we assume that the law of one price does not hold (such as $P_{k, t}^{i} \neq P_{k, t}^{k}$ and $P_{w, t}^{i} \neq S_{t} P_{w, t}^{w}$ ). There is, thus, incomplete exchange rate pass-through in the model. Similar to the home good retailers, imported goods retailers set prices according to a Calvo-style price setting equation. Their optimization problems are identical except for real marginal costs. The

latter are, respectively, $\left(\frac{P_{k, t}^{k}}{P_{k, t}^{i}}\right) \equiv L O P G_{k, t}^{i}$ and $\left(\frac{S_{t} P_{w, t}^{w}}{P_{w, t}^{i}}\right) \equiv L O P G_{w, t}^{i}$ for imported goods from the RoU and the RoW. The inflation rates for imported goods then satisfy these following New Keynesian Phillips curves:

$$
\begin{aligned}
& \hat{\pi}_{k, t}^{i}=\beta E_{t} \hat{\pi}_{k, t+1}^{i}+\frac{\left(1-\phi^{i}\right)\left(1-\beta \phi^{i}\right)}{\phi^{i}} \widehat{\operatorname{lopg}}_{k, t}^{i} \\
& \hat{\pi}_{w, t}^{i}=\beta E_{t} \hat{\pi}_{w, t+1}^{i}+\frac{\left(1-\phi^{i}\right)\left(1-\beta \phi^{i}\right)}{\phi^{i}} \widehat{\operatorname{lopg}}_{w, t}^{i}
\end{aligned}
$$

where $\pi_{k, t}^{i}$ and $\pi_{w, t}^{i}$ are imported inflation prices from the RoU and the RoW.

Finally, from equation (9), CPI inflation, $\hat{\pi}_{t}^{i}$, is a composite of domestic, foreign and world goods prices inflation, such that:

$$
\hat{\pi}_{t}^{i}=\left(1-a_{1}^{i}-a_{2}^{i}\right) \hat{\pi}_{i, t}^{i}+a_{1}^{i} \hat{\pi}_{k, t}^{i}+a_{2}^{i} \hat{\pi}_{w, t}^{i}
$$

$\forall i, k \in\{h, f\}$ and $i \neq k$.

\subsection{Banks}

Competitive banks make financial intermediation. The purpose of financial intermediary in the model is to allow fiscal and monetary policies to influence the economy via the bank-lending channel. At the beginning of each period $t$, the representative bank takes deposits, $D_{t}^{i}$, from the representative household and lends to domestic entrepreneurs, domestic government and foreign government (in the RoU). Bank loans are defined by $L_{t}^{i}$ and assumed to take the following form:

$$
L_{t}^{i}=\varepsilon_{t}^{i} D_{t}^{i}
$$

where $\varepsilon_{t}^{i} \in[0,1]$ denotes the fraction of total deposits lent out to entrepreneurs and governments of the monetary union. The remaining portion of deposits, $\left(1-\varepsilon_{t}^{i}\right)$, is held as reserves that earn no interest. Following Atta-Mensah and Dib (2008), we assume that the intermediation process $\varepsilon_{t}^{i}$ is partly endogenous and depends on the state of the economy in this way: 


$$
\varepsilon_{t}^{i}=\left(\frac{Y_{t}^{i}}{Y^{i}}\right)^{\epsilon} Z_{\epsilon, t}^{i}
$$

The parameter $\epsilon$ is the elasticity of the willingness to lend with respect to changes in economic activity (deviations of output from its steady-state value) and $Z_{\epsilon, t}^{i}$ represents shocks to the intermediation process. If the willingness to lend is pro-cyclical, then $\epsilon>0$. This can be justified by the fact that, in good times, net worth of entrepreneurs and governments' fiscal receipts are relatively high. This improves the credit risks of borrowers and increases the willingness of financial intermediaries to lend. The process for $Z_{\epsilon, t}^{i}$ is given by:

$$
\log \left(Z_{\epsilon, t}^{i}\right)=\rho_{\epsilon} \log \left(Z_{\epsilon, t-1}^{i}\right)+e_{\epsilon, t}
$$

The shock $Z_{\epsilon, t}^{i}$ could represent, for example, an exogenous change in the confidence level of bank with respect to the credit risks of their borrowers and the health of the economy ${ }^{8}$.

Next, we assume that banks provide the fixed shares of their loans to entrepreneurs, foreign government and domestic government. These shares are, respectively, $\zeta_{E}^{i}, \zeta_{k}^{i}$ and $\left(1-\zeta_{k}^{i}-\zeta_{E}^{i}\right)$. At the end of period $t$, the representative bank receives, in principal and interest, $R_{L, t}^{i} \Psi_{\mathrm{E}, t}^{i}(\cdot)\left(\zeta_{E}^{i} L_{t}^{i}\right)$ from entrepreneurs, $R_{L, t}^{i} \Psi_{l, t}^{k}\left(l_{t}^{i}, l_{t}^{k}, Z_{l, t}^{k}\right)\left(\zeta_{k}^{i} L_{t}^{i}\right)$ from foreign government in the RoU and $R_{L, t}^{i}\left(1-\zeta_{k}^{i}-\right.$ $\left.\zeta_{E}^{i}\right) L_{t}^{i}$ from domestic government. We assumed that domestic government loan cost is the benchmark for banks to decide which costs must be applied on the others agents' loans. Therefore, banks provide loans in a way consistent with a portfolio management goal (changing the cost of borrowing of each agent), and the variable $R_{L, t}^{i}$ is the gross nominal interest rate on domestic government loans.

The relative risk premia are defined as follows: $\Psi_{\mathrm{E}, t}^{i}(\cdot)$ is entrepreneur's external finance premium as previously defined and $\Psi_{l, t}^{k}\left(l_{t}^{i}, l_{t}^{k}, Z_{l, t}^{k}\right)$, defined in section 2.5 below, is the relative risk premium paid by government $k$. Banks owe $R_{t} D_{t}^{i}$ to depositors and earn a zero net return on their reserves. In this case, the bank profit function is given by:

$$
\begin{aligned}
\Pi_{l, t}^{i}= & R_{L, t}^{i}\left(1-\zeta_{k}^{i}-\zeta_{E}^{i}\right) L_{t}^{i}+R_{L, t}^{i} \Psi_{l, t}^{k} \zeta_{k}^{i} L_{t}^{i}+R_{L, t}^{i} \Psi_{\mathrm{E}, \mathrm{t}}^{i}(\cdot) \zeta_{E}^{i} L_{t}^{i}+D_{t}^{i}-R_{t} D_{t}^{i}-\left(1-\zeta_{k}^{i}-\zeta_{E}^{i}\right) L_{t}^{i}- \\
& \zeta_{k}^{i} L_{t}^{i}-\zeta_{E}^{i} L_{t}^{i}
\end{aligned}
$$

Given the competition among banks for loans and deposits, the zero profit condition guarantees that:

$$
R_{L, t}^{i}=\frac{R_{t}-1+\varepsilon_{t}^{i}}{\left[1+\zeta_{k}^{i}\left(\Psi_{l, t}^{k}-1\right)+\zeta_{E}^{i}\left(\Psi_{\mathrm{E}, \mathrm{t}}^{i}-1\right)\right] \varepsilon_{t}^{i}}
$$

The fluctuations in the reserve levels of banks are captured by the parameter epsilon and would be reflected in the gap between loan and deposit interest rates. Equation (42) shows that the loans interest rate applied to domestic government decreases when risk premia of relative risky agents increases, and thus when their debts increase.

\footnotetext{
${ }^{8}$ The other possible sources of variation in $Z_{\epsilon, t}^{i}$ are: perceived changes in entrepreneur's cash flow or net worth, government regulation of banks, technological advances in the intermediation process (Berger, 2003).
} 


\subsection{Government Budget Constraint and Fiscal policy}

In each economy, government spends in purchases of aggregate goods $G_{t}^{i}$ and transfers to households $T R_{t}^{i}$. To do that, the government collects tax revenues on consumption and capital income, and receives loans from domestic and foreign banks $\left(\left(1-\zeta_{k}^{i}-\zeta_{E}^{i}\right) L_{t}^{i}\right.$ and $\zeta_{i}^{k} L_{t}^{k}$ respectively).

The government budget constraint is given by:

$$
\left(1-\zeta_{k}^{i}-\zeta_{E}^{i}\right) L_{t}^{i}+\zeta_{i}^{k} L_{t}^{k}=R_{L, t-1}^{i}\left(1-\zeta_{k}^{i}-\zeta_{E}^{i}\right) L_{t-1}^{i}+R_{L, t-1}^{i} \Psi_{l, t}^{i}\left(l_{t}^{i}, l_{t}^{k}, Z_{l, t}^{i}\right)\left(\zeta_{i}^{k} L_{t-1}^{k}\right)+P D_{t}^{i}
$$

In equation (43), $P D_{t}^{i}$ is the nominal primary deficit and expressed by:

$$
P D_{t}^{i}=P_{t}^{i} G_{t}^{i}+T R_{t}^{i}-\tau_{c, t}^{i} P_{t}^{i} C_{t}^{i}-\tau_{K, t}^{i} m p c_{t}^{i} K_{t}^{i} P_{t}^{i}
$$

The term $\Psi_{l, t}^{i}\left(l_{t}^{i}, l_{t}^{k}, Z_{l, t}^{i}\right)$ is the government $i$ ' relative risk premium such that,

$$
\Psi_{l, t}^{i}\left(l_{t}^{i}, l_{t}^{k}, Z_{l, t}^{i}\right) \equiv \exp \left(\psi_{l}^{i}\left(\frac{\left(1-\zeta_{k}^{i}-\zeta_{E}^{i}\right) L_{t}^{i}+\zeta_{i}^{k} L_{t}^{k}}{Y^{i} P_{t}^{i}}\right)+Z_{l, t}^{i}\right)
$$

where $\psi_{l}^{i}$ is the elasticity of the risk premium with respect to government debt; $l_{t}^{i} \equiv \frac{L_{t}^{i}}{Y^{i} P_{t}^{i}}$ and $l_{t}^{k} \equiv \frac{L_{t}^{k}}{Y^{k} P_{t}^{k}}$ are respectively the total of loans made by banks in economy $i$ and $k ; Z_{l, t}^{i}$ is an exogenous shock on government's premium and evolves according to the following autoregressive process:

$$
\log \left(Z_{l, t}^{i}\right)=\rho_{l} \log \left(Z_{l, t-1}^{i}\right)+e_{l, t}
$$

\section{Fiscal policy instruments}

The government needs to adjust tax revenues or expenditure to stabilize its deficit and debt. We choose public spending as the fiscal policy instrument. Government spending adjustments in response to cyclical fluctuations are endogenously made according to the fiscal rule:

$$
\log \left(\frac{G_{t}^{i}}{G^{i}}\right)=\rho_{g} \log \left(\frac{G_{t-1}^{i}}{G^{i}}\right)-(c g)\left(1-\rho_{g}\right) \rho_{g y} \log \left(\frac{Y_{t}^{i}}{Y^{i}}\right)-\left(1-\rho_{g}\right) \rho_{g l} \log \left(\frac{D Y_{t}^{i}}{D Y^{i}}\right)+e_{g, t}
$$

where $\rho_{g}, \rho_{g y}, \rho_{g l} \in[0,1]$ capture, respectively, the degree of public spending smoothing, fiscal reaction to output deviation and fiscal reaction to debt/GDP ratio $\left(D Y_{t}^{i} \equiv \frac{\left(1-\zeta_{k}^{i}-\zeta_{E}^{i}\right) L_{t}^{i}+\zeta_{i}^{k} L_{t}^{k}}{Y^{i} P_{t}^{i}}\right) ; e_{g, t}$ is an exogenous shock to government spending $\left(e_{g, t} \sim\right.$ i.i.d. $\left.\left(0, \sigma_{e_{g}}^{2}\right)\right)$.

The parameter $(c g)$ captures the degree of fiscal policy cyclicality. If $(c g)=1$ (resp. $(c g)=-1)$, public spending is counter-cyclical (resp. pro-cyclical). 
As for the other fiscal instruments, government transfers, taxes on consumption and capital income follow an autoregressive process:

$$
\begin{gathered}
\log \left(\frac{T R_{t}^{i}}{T R^{i}}\right)=\rho_{t r} \log \left(\frac{T R_{t-1}^{i}}{T R^{i}}\right)+e_{t r, t} \\
\log \left(\frac{\tau_{c, t}^{i}}{\tau_{c}^{i}}\right)=\rho_{\tau c} \log \left(\frac{\tau_{c, t}^{i}}{\tau_{c}^{i}}\right)+e_{\tau c, t} \\
\log \left(\frac{\tau_{K, t}^{i}}{\tau_{K}^{i}}\right)=\rho_{\tau K} \log \left(\frac{\tau_{K, t}^{i}}{\tau_{K}^{i}}\right)+e_{\tau K, t}
\end{gathered}
$$

where, $\rho_{x} \in[0,1]$, with $x=t r, \tau c$ and $\tau K$, are the coefficients of the autoregressive process and $e_{x, t} \sim$ i.i.d $\left(0, \sigma_{e_{x}}^{2}\right)$ are the associated exogenous shocks.

\subsection{Monetary authority}

In the monetary union, the common central bank sets the nominal interest rate according to the following Taylor-type interest rate rule:

$$
\log \left(\frac{R_{t}}{R}\right)=\beta_{0} \log \left(\frac{R_{t-1}}{R}\right)+\left(1-\beta_{0}\right)\left[\beta_{1} \log \left(\frac{E_{t} \pi_{t+1}^{u m}}{\pi^{u m}}\right)+\beta_{2} \log \left(\frac{Y_{t}^{u m}}{Y^{u m}}\right)\right]+e_{r, t}
$$

with $e_{r, t} \sim$ i.i.d. $\left(0, \sigma_{e_{r}}^{2}\right)$.

$R, \pi^{u m}$ and $Y^{u m}$ are the steady-state values of $R_{t}, \pi_{t}^{u m}$ and $Y_{t}^{u m}$, that are, respectively, the nominal interest rate, the inflation rate and output of the union. The variables $\pi_{t}^{u m}$ and $Y_{t}^{u m}$ are the average values of inflation and output of the two equal-size countries:

$\pi_{t}^{u m}=\frac{1}{2}\left(\pi_{t}^{h}+\pi_{t}^{f}\right)$ and $Y_{t}^{u m}=\frac{1}{2}\left(Y_{t}^{h}+Y_{t}^{f}\right)$

$\beta_{1}>1$ and $\beta_{2}<1$ are coefficients that measure central bank responses to expected inflation and output deviations. The parameter $0<\beta_{0}<1$ captures the degree of interest rate smoothing.

\subsection{General equilibrium conditions}

In equilibrium, the factor markets, the final goods market, the loan market and the international traded bonds market must clear in each country $i \in\{h, f\}$.

Equilibrium in factor markets requires:

$$
N_{t}^{i}=\int_{0}^{1} N_{t}^{i}(j) d j \text { and } K_{t}^{i}=\int_{0}^{1} K_{t}^{i}(j) d j
$$


The loan market clears when the unused fraction of household deposits in reserves by financial intermediaries equalizes the total funds lent to entrepreneurs, domestic government and government in the RoU (see equation 38 supra).

Let $Y_{t}^{i} \equiv\left(\int_{0}^{1} Y_{t}^{i}(j)^{\frac{\chi-1}{\chi}} d_{j}\right)^{\frac{\chi}{\chi-1}}$ denote aggregate output. Thus, the goods market clearing condition satisfies:

$$
Y_{t}^{i}=C_{i, t}^{i}+I_{i, t}^{i}+G_{i, t}^{i}+E X_{t}^{i}
$$

where $E X_{t}^{i}=a_{1}^{i}\left(\frac{P_{i, t}^{i}}{P_{t}^{k}}\right)^{-\theta} A B_{t}^{k}+a_{2}^{i}\left(\frac{P_{i, t}^{i}}{S_{t} P_{t}^{w}}\right)^{-\theta} A B_{t}^{w}$

The variable $E X$ represents total exports and $A B$ stands for absorption.

Then the domestic economy's aggregate resource constraint can be rewritten as:

$$
Y_{t}^{i}=\left(\frac{P_{i, t}^{i}}{P_{t}^{i}}\right)^{-\theta}\left[\left(1-a_{1}^{i}-a_{2}^{i}\right) A B_{t}^{i}+a_{1}^{i}\left(\frac{1}{R E R_{k, t}^{i}}\right)^{-\theta} A B_{t}^{k}+a_{2}^{i}\left(\frac{1}{R E R_{w, t}^{i}}\right)^{-\theta} A B_{t}^{w}\right]
$$

where $A B_{t}^{i}, A B_{t}^{k}$ and $A B_{t}^{w}$ are, respectively, absorption in the domestic economy, RoU and the RoW. We have:

$$
\begin{aligned}
& A B_{t}^{i}=C_{t}^{i}+I_{t}^{i}+G_{t}^{i} \\
& A B_{t}^{k}=C_{t}^{k}+I_{t}^{k}+G_{t}^{k}
\end{aligned}
$$

and $A B_{t}^{w}$ is an exogenous process.

The internationally traded bonds market is in equilibrium when the positions of the export and importing firms vis-à-vis the RoW equals the households' choice of internationally traded bonds holdings. The evolution of net foreign assets (government assets holdings from the RoU plus households internationally traded bonds holdings) at the aggregate level can be expressed as:

$$
\begin{aligned}
S_{t} B_{w, t}^{i}+\zeta_{i}^{k} L_{t}^{k} & =S_{t} R_{w, t-1} \Psi_{b, t-1}^{i}\left(b_{t-1}^{i}, Z_{t-1}^{i}\right) B_{w, t-1}^{i}+R_{L, t-1}^{i} \Psi_{l, t-1}^{i}\left(l_{t-1}^{i}, l_{t-1}^{k}, Z_{l, t-1}^{i}\right) \zeta_{i}^{k} L_{t-1}^{k}+E X_{t}^{i} \\
& -\left(I M_{k, t}^{i}+I M_{w, t}^{i}\right)
\end{aligned}
$$

where $I M_{k, t}^{i}$ and $I M_{w, t}^{i}$ are imports of country $i$ originating from country $k$ (of the RoU) and from the RoW, respectively.

Noting that the definitions of $b_{t}^{i}, l_{t}^{i}$ and $l_{t}^{k}$ are $b_{t}^{i} \equiv \frac{s_{t} B_{w, t}^{i}}{Y P_{t}^{i}}, l_{t}^{i} \equiv \frac{L_{t}^{i}}{Y^{i} P_{t}^{i}}$ and $l_{t}^{k} \equiv \frac{L_{t}^{k}}{Y^{k} P_{t}^{k}}$, we can write the evolution of total real NFA position in percentage of steady-state output as:

$$
\begin{aligned}
& b_{t}^{i}+\zeta_{i}^{k} l_{t}^{k} \frac{P_{t}^{k}}{P_{t}^{i}}=\frac{R_{w, t-1} \Psi_{b, t-1}^{i}}{\pi_{t}^{i}} b_{t-1}^{i}+\frac{R_{L, t-1}^{i} \Psi_{l, t-1}^{i}}{\pi_{t}^{i}} \zeta_{i}^{k} l_{t-1}^{k} \frac{P_{t-1}^{k}}{P_{t-1}^{i}}+\frac{1}{Y}\left(\frac{P_{i, t}^{i}}{P_{t}^{i}} Y_{t}^{i}-C_{t}^{i}-I_{t}^{i}-G_{t}^{i}\right) \\
& \forall i, k \in\{h, f\} \text { and } i \neq k .
\end{aligned}
$$




\subsection{Rest of the world}

We assume that the RoW is fully exogenous and its variables follow an autoregressive process such that:

$$
\begin{aligned}
& \log \left(A B_{t}^{w}\right)=\rho_{A B w} \log \left(A B_{t-1}^{w}\right)+e_{A w, t} \\
& \log \left(R_{w, t}\right)=\rho_{R w} \log \left(R_{w, t-1}\right)+e_{r w, t} \\
& \log \left(\pi_{w, t}\right)=\rho_{\pi w} \log \left(\pi_{w, t-1}\right)+e_{\pi w, t}
\end{aligned}
$$

where $\rho_{x} \in[0,1]$ with $x=A B w, R w$ and $\pi w$ are the coefficients of autoregressive process and $e_{x, t} \sim$ i.i.d $\left(0, \sigma_{e_{x}}^{2}\right)$ are the associated exogenous shocks.

\section{Calibration of the model and simulations of real and financial shocks}

\subsection{Calibration of the model}

We log-linearized the equations of the model around the steady state. ${ }^{9}$ We then used the software Dynare to do the simulations. The calibration of the model and the main macroeconomic steady-state ratios are summarized in Table 1 below. Calibration is made according to the references found in the literature for the euro area (on average) or according to our own computation based on the ECB, OECD and European Commission (AMECO) databases.

We simulate two types of asymmetric shocks hitting the domestic country: 1) a positive technological shock and 2) a default risk premium shock. For both shocks, we study the effects on the domestic economy and the spillover effects on the economy of the partner country (RoU). In particular, special attention is given to two mechanisms: the evolution and financing of public debt and the impact of the openness of the union toward the RoW. We consider first a technological shock because we want to generate higher economic growth in one country of the monetary union and study the consequences of a pro-cyclical stance of fiscal policy in the domestic country. Thus, we compare two opposite cases concerning the behaviour of public spending in response to the output gap in the domestic country: it is either counter-cyclical (the parameter $c g$ is equal to 1) or pro-cyclical ( $c g=$ $-1)$. In contrast, public spending remains countercyclical in the RoU in all cases. As for the default risk premium shock, we think of it as a case where one country of the monetary union is faced with a sudden change in expectations of the financial markets about the sovereign debt sustainability (assuming that the domestic country has a pro-cyclical fiscal policy). In addition, we assume that the elasticity of the sovereign risk premium to the level of public debt is higher in both countries of the monetary union ( $\psi_{l}^{i}=0.1$ instead of 0.01 ). This assumption relies on the idea that traders of government bonds in financial markets will react to any change in the level of public indebtedness more than they used to and whatever the country.

\footnotetext{
${ }^{9}$ The linearized version of the model is available upon request.
} 
Table 1. Baseline calibration of the DSGE model

\begin{tabular}{|c|c|c|c|}
\hline Description & Parameter & Value & References \\
\hline Inverse intertemporal elasticity of substitution & $\sigma$ & 2 & Literature on the EA \\
\hline Inverse of the Frisch elasticity of labour supply & $\eta$ & 1 & Literature on the EA \\
\hline Subjective discount factor & $\beta$ & 0.99 & Literature on the EA \\
\hline Habit persistence coefficient & $h$ & 0.85 & Literature on the EA \\
\hline Share of imported goods from the rest of the union & $a_{1}^{i}$ & 0.21 & AMECO database \\
\hline Share of imported goods from the rest of the world & $a_{2}^{i}$ & 0.11 & AMECO database \\
\hline Elasticity of substitution between domestic and imported goods & $\theta$ & 1.5 & Coenen et al. (2008) \\
\hline Elasticity of the risk premium with respect to NFA position & $\psi_{b}^{i}$ & 0.001 & $\begin{array}{l}\text { Schmitt-Grohé and Uribe } \\
\text { (2003) }\end{array}$ \\
\hline Capital contribution to production & $\alpha$ & 0.36 & OECD database \\
\hline Capital depreciation rate & $\delta$ & 0.025 & Literature on the EA \\
\hline Internal capital adjustment costs parameter & $\psi_{I}$ & 0.25 & Literature on the EA \\
\hline Fraction of retailers keeping their prices unchanged & $\phi_{i}$ & 0.8 & Literature on the EA \\
\hline $\begin{array}{l}\text { Elasticity of the external finance premium with respect to firm's } \\
\text { leverage ratio }\end{array}$ & $\gamma$ & 1 & Literature on the EA \\
\hline Firms' probability of leaving the economy & $1-v$ & 0.272 & Bernanke et al. (1999) \\
\hline Share of banking loans to firms & $\zeta_{E}^{i}$ & 0.65 & ECB database \\
\hline Share of banking loans to foreign government (in the RoU) & $\zeta_{k}^{i}$ & 0.195 & ECB database \\
\hline Elasticity of risk premium with respect to government debt & $\psi_{l}^{i}$ & $0.01 / 0.1$ & Simulations \\
\hline $\begin{array}{l}\text { Elasticity of the willingness to lend with respect to changes in } \\
\text { economic activity }\end{array}$ & $\varepsilon$ & 1.82 & ECB database \\
\hline \multicolumn{4}{|l|}{ Steady State Macroeconomic Ratios } \\
\hline Capital / GDP ratio & $\bar{K} / Y$ & 8 & AMECO database \\
\hline Consumption/GDP ratio & $C / Y$ & 0.6 & AMECO database \\
\hline Investment /GDP ratio & $I / Y$ & 0.2 & AMECO database \\
\hline Public expenditures/GDP ratio & $G / Y$ & 0.2 & AMECO database \\
\hline Transfers/GDP ratio & $\operatorname{Tr} / Y$ & 0.13 & AMECO database \\
\hline \multicolumn{4}{|l|}{ Monetary and fiscal policy } \\
\hline Smoothing coefficient in the monetary rule & $\beta_{0}$ & 0.8 & Literature on the EA \\
\hline Inflation stabilizing coefficient in the monetary rule & $\beta_{1}$ & 2 & Literature on the EA \\
\hline Output stabilizing coefficient in the monetary rule & $\beta_{2}$ & 0.1 & Literature on the EA \\
\hline Smoothing coefficient in the public expenditure rule & $\rho_{g}$ & 0.8 & Coenen et al. (2008) \\
\hline Output stabilizing coefficient in the public expenditure rule & $\rho_{g y}$ & 0.3 & Christoffel et al. (2011) \\
\hline Debt stabilizing coefficient in the public expenditure rule & $\rho_{g l}$ & 0.01 & Christoffel et al. (2011) \\
\hline Tax rate on consumption & $\tau_{c}$ & 0.20 & EC data \\
\hline Tax rate on capital income & $\tau_{k}$ & 0.25 & EC data \\
\hline \multicolumn{4}{|l|}{ Shocks } \\
\hline Coefficients of autoregressive process for technology & $\rho_{a}$ & 0.6 & \\
\hline $\begin{array}{l}\text { Coefficients of autoregressive process for shock on government's } \\
\text { premium }\end{array}$ & $\rho_{l}$ & 0.5 & \\
\hline
\end{tabular}




\subsection{Technological shock analysis}

Figure 1 displays the effects of a positive technological shock in the domestic country on the domestic economy. The spillover effects on the RoU are displayed in Figure 2. We have the usual impact of a positive technological shock: higher output, higher investment, higher consumption and lower inflation compared to the steady-state level in the domestic country. As a consequence, the latter becomes more competitive within the union and with regard to the RoW (real effective depreciation of domestic goods relative to foreign goods). The common central bank lowers the common short-term nominal interest rate less than the fall in the average rate of inflation in the union (the average output gap in the union is positive). As a result, the real interest rate is positive in both countries. Since the rental rate of capital decreases much in the domestic economy (given the decline in the marginal productivity of capital), the domestic government collects fewer tax receipts on capital income. This negative effect on the government revenues is greater than the positive effect of higher receipts from the tax on consumption.

In the case of a counter-cyclical fiscal rule, public consumption is lower. Nevertheless, the ratio of public debt to GDP rises because the decline in total tax revenues is larger than the decline in primary public expenditures. In the pro-cyclical fiscal policy scenario, public consumption increases and the increase in the public debt-to-GDP ratio is less strong than in the counter-cyclical case in the short term, because output is higher in the pro-cyclical case. In the latter case, the nominal effective depreciation of the common currency is stronger (in order to get the balance of payments back to equilibrium). And a stronger real effective depreciation leads to more exports of goods to the RoW. Yet, in the long term, the ratio of public debt to GDP goes back to its steady-state level much faster in the counter-cyclical case than in the pro-cyclical case.

Initially, the interest rate on public bonds is lower because the effect of a lower key interest rate (set by the central bank) is stronger than the effect of a higher sovereign risk premium. After the initial impact of the shock, the interest rate on public bonds increases more in the counter-cyclical case than in the pro-cyclical case, because the ratio of public debt to GDP is higher in the former case (given a lower output gap). As for the cost of borrowing for the private sector, it is lower at the moment of the shock. Banks set the interest rate on loans to the private sector by adding an external finance premium to a reference rate (that is the interest rate on public bond). Apart from the lower reference rate (at the beginning), firms enjoy a lower risk premium because they are perceived relatively less risky than governments (whose indebtedness is increasing). 
Figure 1. Technological shock and fiscal policy: effects on domestic country
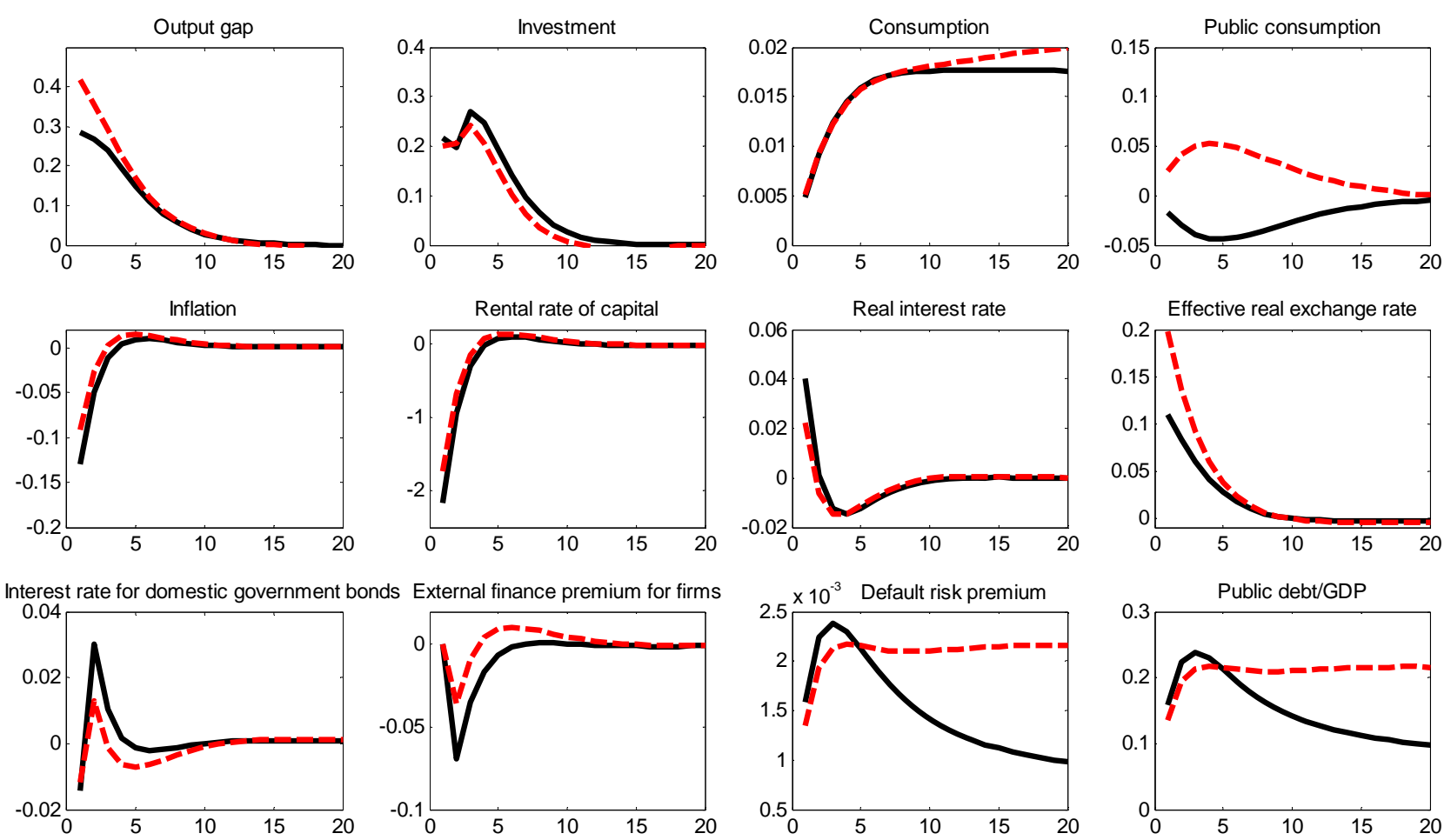

counter-cyclical fiscal scenario $-\boldsymbol{- a}$ pro-cyclical fiscal scenario

For the partner country in the RoU, a pro-cyclical stance of fiscal policy in the domestic country amplifies negative spillover effects on consumption and investment (figure 2). Private consumption and investment fall more because the real interest rate is higher than in the case where the domestic country implements a counter-cyclical fiscal policy. This is due to a stronger fall in prices (accentuated by lower imported inflation). Moreover, the central bank does not lower sufficiently the common nominal interest rate (given that it is set according to average values of the economic variables of the member countries). Yet, output can increase in the RoU as long as exports of goods towards the RoW can increase. As a matter of fact, for the RoU, there is a real appreciation of goods with regard to the domestic country but there is also a real depreciation of goods with regard to the RoW (given the nominal depreciation of the common currency). This effect on exports to the RoW more than offsets the negative direct spillover effects on consumption and investment. Higher exports of goods to the RoW imply that there is a need to produce more with the same amount of capital. A higher productivity of capital translates into a higher rental rate of capital.

The RoU benefits from an increase in fiscal revenues from taxes on capital income. Public consumption decreases more in the case of a pro-cyclical fiscal policy in the domestic country than in the case of a counter-cyclical fiscal policy, because output in the RoU is (slightly) higher in the former case (public consumption is counter-cyclical in the RoU). As a consequence, public debt decreases in the RoU and the sovereign risk premium decreases too. During the process of going back to the long-term equilibrium, the RoU is faced with a fall in the effective real exchange rate (a real appreciation), a decrease in exports of goods towards the RoW, a decrease in output, an increase in public primary expenditures, an increase in consumption tax receipts but a decrease in capital 
income tax receipts, and an increase in public debt (back to the steady-state level). There will be an increase in the interest rate on public bonds and firms can enjoy a relatively lower cost of borrowing, if the fall in the external finance premium (they are perceived relatively less risky than governments) can compensate for the rise in the reference rate (interest rate on public bonds).

Figure 2. Technological shock and fiscal policy: effects on the RoU
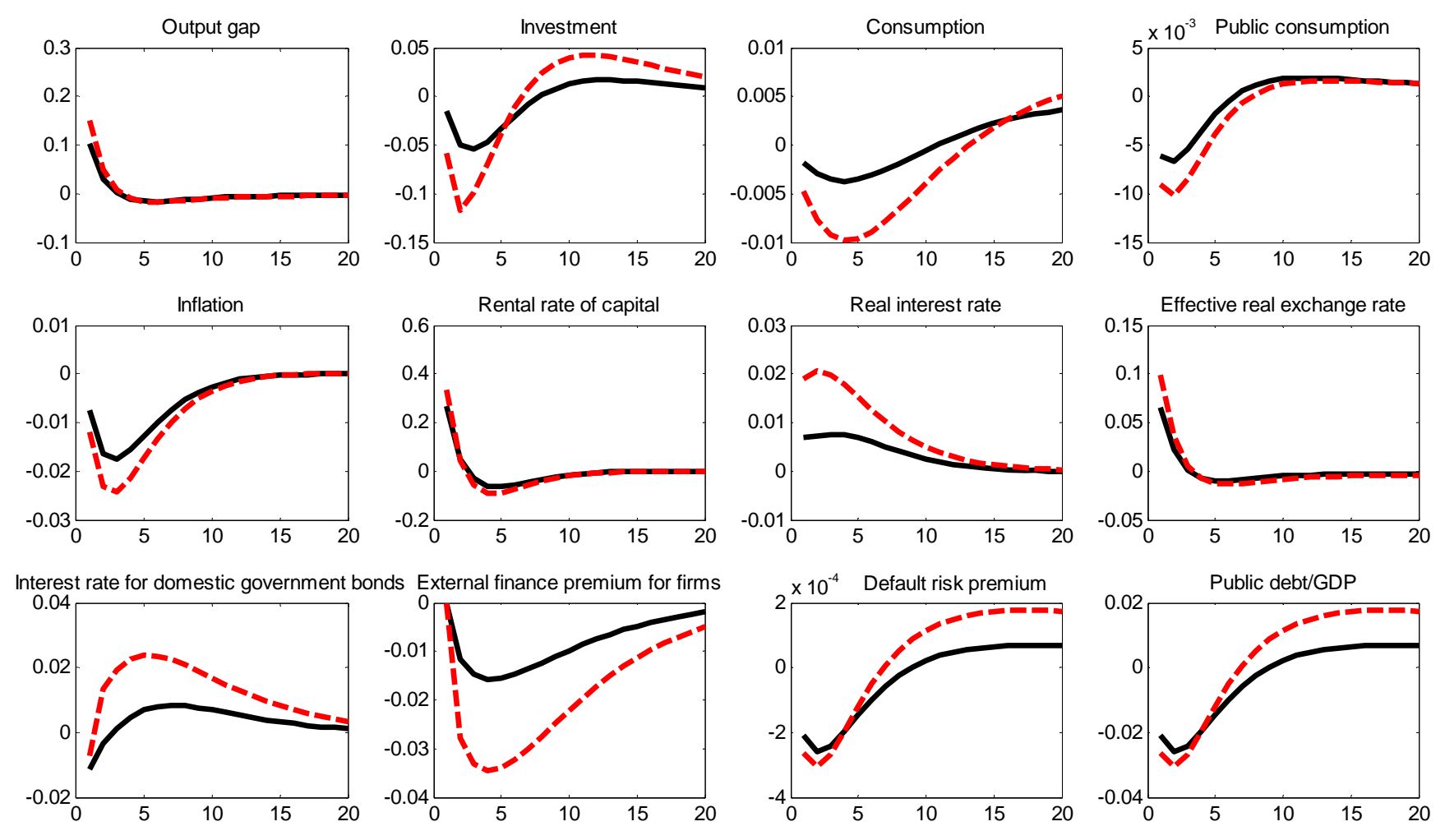

counter-cyclical fiscal scenario $\square=$ pro-cyclical fiscal scenario

Note: fiscal policy is either counter-cyclical or pro-cyclical in the domestic country hit by the technological shock. But it is always counter-cyclical in the RoU.

All in all, the model shows that the real interest rate is a key variable in causing macroeconomic divergences between countries of the monetary union while the (extra-union) real exchange rate lessens these divergences. Pro-cyclical public primary expenditures in the domestic country, where higher output growth is generated by a positive technological shock, accentuate the negative spillover effects on consumption and investment in the partner country (RoU). In the domestic country, the ratio of public debt to GDP increases less in the short-term than in the case of a counter-cyclical fiscal policy, because pro-cyclical public spending amplifies output growth. However, it takes far more time to get the public debt/GDP ratio back to its steady-state level. Some governments may tend to neglect the long-term effects of their pro-cyclical fiscal policy. The rise in the domestic public debt makes the private sectors in the domestic economy and in the RoU relatively less risky. As a consequence, there are some positive financial effects for private agents, at least in the short-term. As regards the public sector in the RoU, there are lower costs of borrowing but only in the very shortterm. 


\subsection{Sovereign risk premium analysis}

The domestic country is now hit by a financial shock: a higher sovereign risk premium. Figure 3 depicts the effects on the domestic economy (straight line) and on the RoU (dotted line) in the case where fiscal policy is pro-cyclical in the domestic country but counter-cyclical in the RoU. This shock makes the government of domestic country relatively riskier than the government in the RoU. As a consequence, the optimal behaviour of banks implies a higher interest rate on domestic sovereign bonds and a lower interest rate on foreign sovereign bonds. As regards the private sector, the cost of borrowing hardly changes in the domestic economy because the higher reference rate (interest rate on public bonds) is almost matched by a lower external finance premium. In the RoU, the cost of borrowing for private sector declines a bit because the fall in the interest rate on public bonds is slightly larger than the increase in the external finance premium (the private sector being perceived by banks as relatively riskier than the public sector in the RoU). Thus, the higher sovereign risk premium in the domestic country lowers the cost of borrowing in the RoU. Consequently, in the RoU, there is an increase in investment, output and inflation. The fall in the real interest rate leads to higher consumption (the latter gives rise to imports of foreign goods). The domestic economy can grow thanks to exports of goods to the RoU and to the RoW (with a nominal depreciation of the common currency).

Figure 3. Impact of an asymmetric risk premium shock
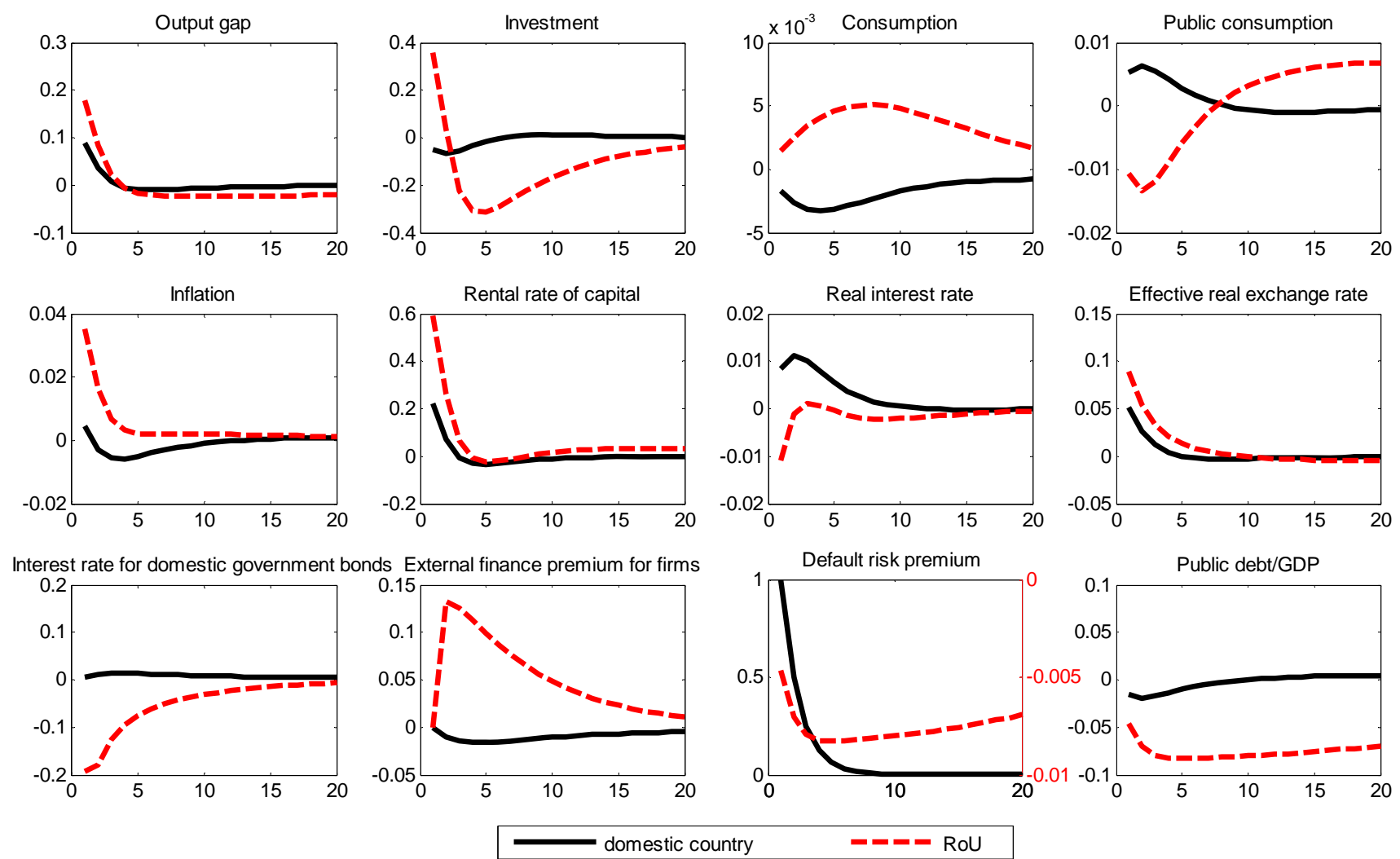
Public consumption decreases in the RoU since it is counter-cyclical and it increases in the domestic country where fiscal spending is pro-cyclical. The foreign government in the RoU benefits from higher tax receipts (both from consumption tax and capital income tax) and lower interest payments. Public debt decreases. In the domestic country, the public debt-to-GDP ratio decreases a bit, despite the shock on the default risk premium. As a matter of fact, the rise in output is due to higher exports and leads to a higher rental rate of capital. The domestic government collects more tax receipts from the tax on capital income.

All in all, the negative impact of the shock on the risk premium on the domestic country is counteracted by a credit channel and a trade channel: as long as the cost of borrowing decreases in the RoU for the public sector and the private sector, higher output growth in the RoU can help the domestic economy to grow faster via intra-union trade. Moreover, the effective real depreciation of the common currency can boost exports towards the RoW. Unfortunately, in the context of the financial crisis and the euro area crisis, world growth was slow and some European countries found it difficult to export more to the rest of the world.

\section{Conclusion}

In this paper, we studied international macroeconomic divergences in a DSGE model of two countries belonging to a monetary union which is open to the rest of the world. We put the focus on divergences in the cyclical stance of national fiscal policies, which may be pro-cyclical in one country and counter-cyclical in the other country. We simulated two asymmetric shocks hitting the domestic country: a positive technological shock and a negative shock on the default risk premium. The model allowed us to explain the spillover effects of these shocks on the economy of the other country in the rest of the union (RoU). We highlighted the role of the evolution of public debt and of the sovereign risk premium in the cost of borrowing for the public sector in the RoU and for the private sectors in the domestic economy and in the RoU. There is also the critical role of external trade with the rest of the world (RoW): an effective real depreciation of the currency of the monetary union which gives rise to exports to the RoW can compensate for the negative effects of a higher real interest rate on consumption and investment within the monetary union.

Under the technological shock, we found that the pro-cyclical fiscal policy in the domestic country leads to a lower increase in the public debt-to-GDP ratio over the short-term than in the countercyclical case because output growth is higher in the former case. However, the public debt remains higher during a far longer period of time. Moreover, the negative spillover effects on consumption and investment in the RoU are stronger. Still, output growth is positive in the RoU via higher exports of goods thanks to a real depreciation of goods relative to the goods produced by the RoW.

A shock on the sovereign risk premium of the domestic country has a negative impact not only on the domestic public sector but also on the domestic private sector. Yet, output growth is possible as long as the country can exports more to the RoU and to the RoW. This shock has some positive effects on the RoU because the lower interest rate on public bonds issued by the governments in the RoU helps to lower the cost of borrowing. Benefits are growing with the openness to the RoW. The model can thus be used to illustrate the economic downturn during the sovereign debt crisis in euro area 
countries with high public indebtedness and low export capacity (such as Greece), and the faster economic recovery in some other countries perceived as less risky and with good performance in external trade (Germany).

Contrary to what Christoffel, Jaccard and Kilponen (2011) found in a closed-economy model, we showed that a procyclical fiscal policy does not necessarily lead to a higher sovereign risk premium at least in the short term because such a policy accentuates output growth and leads to a lower increase in the public debt-to-GDP ratio. In the long term, the sovereign risk premium is higher with a pro-cyclical fiscal policy though, because public debt is higher. Our result is also much dependent on the openness of both countries to the RoW. 


\section{References}

Atta-Mensah J. and A. Dib (2008), "Bank Lending, Credit Shocks, and the Transmission of Canadian Monetary Policy”, International Review of Economics \& Finance, 17(1), pp. 159-176.

Bi H. (2012), “Sovereign Default Risk Premia, Fiscal Limits, and Fiscal Policy”, European Economic Review, 56, pp. 389-410.

Berger A. N. (2003), "The Institutional Memory Hypothesis and the Pro-cyclicality on Bank Lending Behavior”, Federal Reserve Bank of Chicago, Proceedings, May, pp. 151-169.

Bernanke B., M. Gertler S. and Gilchrist (1999), "The Financial Accelerator in a Quantitative Business Cycle Framework", in J.B. Taylor and M. Woodford Eds., Handbook of Macroeconomics, 1, North-Holland.

Calvo G. (1983), "Staggered Prices in a Utility-Maximizing Framework", Journal of Monetary Economics, 12, pp. 383-398.

Christensen Y. and A. Dib (2008), “The Financial Accelerator in an Estimated New-Keynesian Model”, Review of Economic Dynamics, 11(1), pp. 155-178.

Christoffel K., I. Jaccard and J. Kilponen (2011), “Government Bond Risk Premia and the Cyclicality of Fiscal Policy”, ECB Working Paper No. 1411.

Coenen G., P. McAdam and R. Straub (2008), “Tax Reform and Labour-Market Performance in the Euro Area. A Simulation-based Analysis using the New Area-Wide Model”, Journal of Economic Dynamics and Control, 32(8), pp. 2543-2583.

Corsetti G., K. Kuester, A. Meier and G. Mueller (2012), "Sovereign Risk, Fiscal Policy, and Macroeconomic Stability”, IMF Working Paper No. 12/33.

Devereux M. B. \& C. Engel, (2001), “The Optimal Choice of Exchange Rate Regime: Price-Setting Rules and Internationalized Production”, in Topics in Empirical International Economics: A Festschrift in Honor of Robert E. Lipsey, NBER Chapters, National Bureau of Economic Research, pp. 163-194.

Erceg C. and J. Lindé (2012), "Fiscal Consolidation in a Currency Union: Spending Cuts vs. Tax Hikes”, CEPR Discussion Paper No. 9155.

Fatás A. and I. Mihov (2010), "The euro and fiscal policy”, in A. Alesina and F. Giavazzi eds., Europe and the Euro, The University of Chicago Press, Chapter 8, pp. 287-324.

Mody A. and D. Sandri (2011), “The Eurozone Crisis: How Banks and Sovereigns Came to be Joined at the Hip”, IMF Working Paper No. 11/269.

Roeger W. and J. in’t Veld (2013), “Expected Sovereign Defaults and Fiscal Consolidation”, EC Economic Paper No. 479.

Schmitt-Grohe S. and M. Uribe, (2003), “Anticipated Ramsey Reforms and the Uniform Taxation Principle: the Role of International Financial Markets," NBER Working Papers No. 9862.

Smets F. and R. Wouters (2002), “An Estimated Stochastic Dynamic General Equilibrium Model of the Euro Area”, ECB Working Paper No. 171.

Vogel L., W. Roeger and B. Herz (2012), “The Performance of Simple Fiscal Policy Rules in a Monetary Union”, EC Economic Paper No. 470. 


\section{Documents de travail récents}

- Marion Drut: "Vers un système de transport opérant selon les principes de l'économie de la fonctionnalité?" [2013-32]

- Jérôme Héricourt and Sandra Poncet : "Exchange Rate Volatility, Financial Constraints and Trade: Empirical Evidence from Chines" [2013-31]

- Jean-Baptiste Desquilbet et Fédi Kalai : "La banque conventionnelle et la banque islamique avec fonds propres : contrat de dépôt et partage du risque de liquidité" [2013-30]

- Cécily Defoort and Carine Drapier: "Immigration and its dependence on the welfare system: the case of France" [2012-29]

- Carine Drapier and Nadiya Ukrayinchuk : "Les conditions de travail et la santé des immigrés : Seraient- ils plus résistants à la pénibilité au travail que les natifs ?" [2012-28]

- Etienne Farvaque, Muhammad Azmat Hayat and Alexander Mihailov: "Who Supports the ECB?Evidence from Eurobarometer Survey Data" [2012-27]

- Nathalie Chusseau, Joël Hellier and Bassem Ben-Halima: "Education, Intergenerational Mobility and Inequality" [2012-26]

- Nathalie Chusseau and Joël Hellier : "Inequality in Emerging Countries" [201225]

- Nathalie Chusseau and Michel Dumont: "Growing Income Inequalities in Advanced" [2012-24]

- Kirill Borissov and Stéphane Lambrecht : "The dynamics of income inequality in a growthmodel with human capital and occupational choice" [2012-23]

- Thomas Baudin: "More on Religion and Fertility: The French Connection" [2012-22]

- Thomas Baudin, David de la Croix and Paula Gobbi: "DINKs, DEWKs \& Co. Marriage, Fertility and Childlessness in the United States" [2012-21]

- Hamza Bennani: "National influences inside the ECB: an assessment from central bankers' statements" [2012-20]

- Marion Drut : "Vers un système de transport opérant selon les principes de l'économie de la fonctionnalité" [2012-19]

- Jean-François Fagnart et Marc Germain: "Macroéconomie du court terme et politique climatique: Quelques leçons d'un modèle d'offre et demande globales" [2012-18] 